
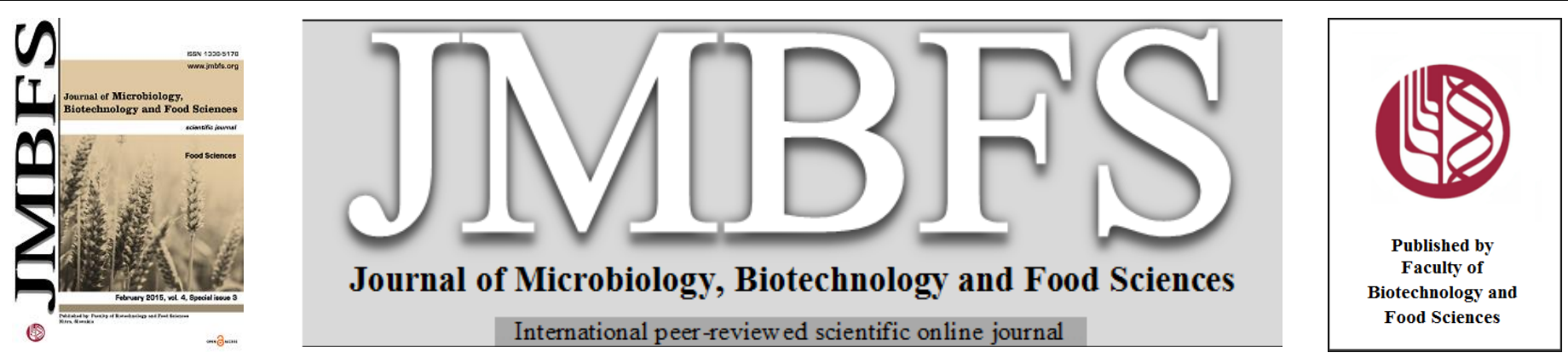

\title{
SENSORY AND TECHNOLOGICAL QUALITY OF SLOVAK VARIETIES OF EDIBLE POTATOES
}

\section{Ján Mareček ${ }^{* 1}$, Janette Musilová ${ }^{2}$, Helena Frančáková ${ }^{1}$, Andrea Mendelová ${ }^{1}$, Tomáš Krajčovič ${ }^{1}$, Jozef Labuda $^{1}$, Ján Heldák $^{3}$}

Address(es): doc. Ing. Ján Mareček, PhD.

${ }^{1}$ Slovak University of Agriculture in Nitra, Faculty of Biotechnology and Food Sciences, Department Plant Products Storage and Processing, Tr. A. Hlinku 2, 94976 Nitra, Slovak Republic, +421 376414379.

${ }^{2}$ Slovak University of Agriculture in Nitra, Faculty of Biotechnology and Food Sciences, Department of Chemistry, Tr. A. Hlinku 2, 94976 Nitra, Slovak Republic.

${ }^{3}$ Potato Research and Breeding Institute, Popradská 517, 05952 Vel'ká Lomnica, Slovak Republic.

*Corresponding author: Jan.Marecek@uniag.sk

doi: 10.15414/jmbfs.2015.4.special3.106-108

\section{ART ICLE INFO}

Received 1. 12.2014

Revised 7. 12. 2014

Accepted 8. 12. 2014

Published 2. 2. 2015

$\frac{\overline{\text { Regular article }}}{{ }_{\text {open }}{ }_{\text {Access }}}$

\section{ABSTRACT}

This scientific work deals with technological and sensory quality examination of a set of nine Slovak potato varieties. Varietal samples were grown and stored at the Potato Research and Breeding Institute in Vel'ká Lomnica (Slovak Republic). Evaluated varieties: Arwen, Evelin, Malvína, Megan, Rumelia, Spinela, Svella, Timea, Viola. Dry matter and starch content of tubers were evaluated from the group of technological parameters. Sensory evaluation was carried out by using the dine value point descriptor. Varietal evaluation was realized from the harvest of 2011 and 2012.Thehighest dry matter content of $21.8 \%$ was measured at variety Rumelia. The starch content was at the same variety at the level of $15.8 \%$. The highest sensory evaluation with very good dine value achieved varieties Evelin (78.0 points) and Spinela (77.8 points). As the best varieties for storage can be used varieties Rumelia, Arwen and Me gan. For heat treatment are most suitable varieties Evelin and Spinela.

Keywords: Potatoes, starch, dine value, dry matter, sensory quality

\section{INTRODUCTION}

Edible potatoes have an important role in the production of agricultural crops and also of produced food raw materials. Currently, the average consumption of edible potatoes in Slovak Republic is around $50 \mathrm{~kg}$ per inhabitant. Potatoes are our raw material used primarily for food (consumption) purposes. On the other hand, there is only a minimal use for industrial purposes. In the varietal composition, we have to take more account of varietal differences, especially in the carbohydrates content and in the options of processing to different products (Mareček et al., 2013).

With gradually changing climate conditions, the need for adaptable varieties is increasing. The most suitable varieties are bred domestically, because they are best adapted to growing conditions. Therefore, the importance of representation and use of domestic potato varieties is increasing. In addition to the adaptability on environment, the chemical composition of tubers is also very important factor. The share of the individual components of tubers influences their technological and sensory quality. External and internal quality characteristics of potato tubers are taken into account, as these factors are influenced by cultivation locality, variety and maturation degree (Mareček et al., 2011).

Potato tubers are characterized by a high proportion of water $(75-80 \%)$ that is mainly represented by free water. Water is involved in the synthesis of various organic compounds; it is also structural component and has a transport function. The dry matter of tubers consists of starch (60-80\% of dry matter) and the other major components (other saccharides, fiber, vitamins, nitrogenous substances, alkaloids and other). The dry matter content is a significant stabilizing factor of tubers. Its value is directly related to the dry matter components content and it also affects the taste properties of tubers (Pobereźny and Wszelaczyńska, 2011).

Starch is quantitatively the most represented component in potato tubers and its content is highest after the harvest of tubers. It decreases during storage as a result of tubers respiration and due to storage conditions. The starch content varies between individual years, as well as the size of the decrease during storage. The varieties cultivated in the area of Central Europe have st arch content in fresh mass in the range of 10-27\%. A higher content is typical for varieties of cooking type C and varieties for industrial use (Bárta $e t$ al., 2008; Mareček $\boldsymbol{e t}$ al., 2014).

In addition to the starch, other saccharides like sucro se, glucose, fruct ose (0.5$3.0 \%$ ) have a significant impact on technological quality. They can affect the taste of tubers (sweetening) and the emergence of dark st ains during the frying of chips (Maillard reaction). Currently, there is examination of the possibility of adding potato material to various food products (bakery products), the use of varieties with colored pulp and their nutritional potential, as well as changes in the material composition during storage (Martens and Thybo, 2000; Wszelaczyńska et al., 2013).

Sensory evaluation of potato tubers can be realized by cooking type (A, B, C) determination according to the European evaluation system, where the tubers cooking ability, consistency, mealiness, dryness, texture, color, taste, smell and darkening are assessed. The point system of dine value determination assesses the quality of tubers before and after steaming, while we evaluate the cooking type only for these steamed tubers. Sensory quality is mostly determined by variety, chemical composition and by the cultivation conditions (soil, water precipitation). Taste of tubers is the most important sensory characteristic after their heat treatment. Consistency of tubers is very important for potatoes heat treated only by steaming (Singh $\boldsymbol{e t ~ a l , ~ 2 0 0 9 ; ~ M a r e c ̌ e k ~} \boldsymbol{e t}$ al., 2011). Ideal is tallowy (salads), slightly mealy (side dishes), or drier and more mealy consistency (potato puree, mashed potatoes)

Aim of this research was to evaluate a set of nine original Slovak varieties. From the harvest of two evaluated years also to analyze varieties in terms of technologicalquality characteristics (dry matter and starch content of tubers), to sensory evaluate and assess the overall quality of each variety.

\section{MATERIAL AND METHODS}

We evaluated nine varieties of edible potatoes (Solanum tuberosum L.): Arwen, Evelin, Malvína, Megan, Rumelia, Spinela, Svella, Timea, Viola.

\section{Material:}

Arwen - medium early variety, cooking type B, yellow peel and pulp, tubers uniformed in size, suitable as a side dish and for peeling purposes;

Evelin - medium early variety, cooking type B, yellow peel and pulp, tubers uniformed in size, suitable as a side dish and for production of fried french fries; Malvín a - early variety, cooking type B, yellow peel and pulp, tubers uniformed in size and shape, suit able as a side dish, for preparation of baked potatoes, potato salads and for washing;

Megan - medium early variety, cooking type B, yellow peel and pulp, tubers uniformed in size, with universal use (as a side dish, baked and roast ed potatoes); 
Rumelia - early variety, cooking type B, red peel and yellow pulp, tubers uniformed in size, suitable as a side dish and for production of

potato puree;

Spinela - medium early variety, cooking type B, red peel and yellow pulp, tubers uniformed in size, suitable as a side dish, for preparation of baked potatoes and for washing;

Svella - very early variety, cooking type B, yellow peel and pulp, tubers uniformed in size, suitable as a side dish;

Timea-medium early variety, cooking type B, yellow peel and pulp, tubers uniformed in size, suitable as a side dish and for production of potato products Viola - early variety, cooking type B, yellow peel with blue shallow eyes, yellow pulp, tubers uniformed in size, suitable as a side dish and for preparation of potato salads.

Tubers of different varieties were grown and bred at Potato Research and Breeding Institute in Vel'ká Lomnica (Slovak Republic). Evaluated samples of these varieties were produced in the years 2011 and 2012.

Tuber samples were placed in storage in October of each year. Storage was performed in cold boxes at $6^{\circ} \mathrm{C}$ and under relative humidity of $87 \%$. Samples were collected according to the variety in quantities of $10 \mathrm{~kg}$. The assessment of sensory quality and selected technological quality parameters of tubers was after the drying and stabilization period of potato tubers (30 days)

All analyzes took place at the Department Plant Products Storage and Processing at Faculty of Biotechnology and Food Sciences of Slovak University of Agriculture in Nitra and at the Potato Research and Breeding Institute in Vel'ká Lomnica (Slovak Republic).

Technological quality parameters:

Dry mater content - drying of the sample to constant weight according to STN ISO 712 ( 3 hours pre-drying at $60^{\circ} \mathrm{C}$ and 3 hours drying at $105^{\circ} \mathrm{C}$ ),

Tuber starch content - determination by Ewers polarimetric method (measurement of component optical activity after the hydrolysis of starch).

Sensory quality parameters: according to ST N 462211 for determination the dine value of potato tubers.

Evaluated sensory characteristics:

A. appearance of fresh unpeeled tubers,
B. tuber appearance on the surface and on cut after steaming,

C. tuber smell,

D. tuber taste and swallow ability,

E. pulp firmness and its cooking ability,

F. darkening of tubers after heat treatment.

Sample preparation was realized by steam heat treatment for 30 minutes at $100^{\circ} \mathrm{C}$. The evaluation was carried out by seven-member sensory committee at the level of trained evaluators. It was a point system evaluation according to the descriptor.

The final classification: excellent value $100-85$ points, very good value $84-75$ points, good value 74-60 points, satisfactory value 59-50 points, unsatisfactory consumerist value - less than 50 points.

\section{RESULTS AND DISCUSSION}

In the varietal group of original Slovak edible potatoes that are allowed for cultivation in Slovakia, a complex findings about their quality are missing. The paper presents chemical and sensory analy sis results of potato varieties originally bred in Slovakia that are currently being grown. They also form the selection database for growers and consumers.

In terms of technological quality parameters were assessed the dry matter and starch content of potato tubers. Measurements of parameters were realized from tuber harvests of 2011 and 2012 and altogether, nine varieties of edible potatoes were evaluated.

The obtained values of tuber dry matter content from the harvest of 2011 fluctuate between 19.3 to $22.3 \%$ (T ab. 1). The highest values were detected in varieties Rumelia $22.3 \%, 21.6 \%$ Megan and $21.4 \%$ Arwen. On the other hand, the lowest values were measured at varieties Evelin $19.5 \%$ and $19.3 \%$ Timea These content characteristics were confirmed by the harvest of 2012. The highes values of dry matter content were at varieties Rumelia $21.3 \%$ and $21.1 \%$ Arwen, while the lowest value was measured at variety Timea $17.7 \%$. Compared to 2011 , the dry matter content was lower in 2012 at all varieties $( \pm 1 \%)$.

Table 1 Technological quality parameters of evaluated varieties (production year 2011-2012)

\begin{tabular}{|c|c|c|c|c|c|c|}
\hline Variety & $\begin{array}{c}\text { dry } \\
\text { matter } \\
\mathbf{2 0 1 1} \\
(\%)\end{array}$ & $\begin{array}{c}\text { dry } \\
\text { matter } \\
\mathbf{2 0 1 2} \\
(\%)\end{array}$ & $\begin{array}{c}\text { starch } \\
2011 \\
(\%)\end{array}$ & $\begin{array}{c}\text { starch } \\
2012 \\
(\%)\end{array}$ & $\begin{array}{c}\text { starch } \\
\text { d. m. } \\
2011 \\
(\%)\end{array}$ & $\begin{array}{c}\text { starch } \\
\text { d. } \mathbf{m} . \\
\mathbf{2 0 1 2} \\
(\%)\end{array}$ \\
\hline Arwen & 21.4 & 21.1 & 15.1 & 14.7 & 70.6 & 69.7 \\
\hline Evelin & 19.5 & 18.5 & 12.6 & 12.7 & 64.6 & 68.7 \\
\hline Malvína & 20.2 & 19.4 & 14.0 & 13.8 & 69.3 & 71.1 \\
\hline Megan & 21.6 & 20.9 & 15.7 & 14.4 & 72.7 & 68.9 \\
\hline Rumelia & 22.3 & 21.3 & 15.9 & 15.7 & 71.3 & 73.7 \\
\hline Spinela & 20.8 & 20.1 & 14.7 & 14.4 & 70.7 & 71.6 \\
\hline Svella & 20.4 & 19.7 & 14.7 & 13.6 & 72.1 & 69.0 \\
\hline Timea & 19.3 & 17.7 & 13.2 & 11.9 & 68.4 & 67.2 \\
\hline Viola & 20.6 & 18.0 & 14.7 & 12.7 & 71.4 & 70.6 \\
\hline
\end{tabular}

On the basis of achieved results, we can include these varieties into the zone of varieties with lower dry matter content. This trend is typical for all varieties grown currently in Slovakia or abroad. Reason for this is shorter vegetation period and cultivation under intensive irrigation. Lower dry matter content may be the result of higher water evaporation or more intensive respiration of tubers during storage. In terms of taste characteristics, lower dry matter content in tubers can cause lower taste fullness and softer consistency of tubers after the heat treatment.

The main dry matter component of potato tubers is a polysaccharide starch Therefore, potatoes are classified as starchy materials. The starch content is usually variable according to the variety and evaluated year (Czerko and Zgórska, 2008). In edible potatoes afterharvest is in the range from 14 to $17 \%$. These values may also be higher depending on type of cultivated varieties. The measured values of starch content from the harvest of 2011 range from $12.6 \%$ to $15.9 \%$. The highest starch levels were identified at varieties Rumelia $15.9 \%$ and $15.7 \%$ Megan. Similarly, in the evaluated year 2012 the highest st arch content was at variety Rumelia $15.7 \%$, while the lowest levels of starch were measured at variety Evelin $(2011-12.6 \%, 2012-12.7 \%)$.

The starch content in dry matter of tubers harvested in 2011 ranged from $64.6 \%$ (Evelin) to $72.7 \%$ (Megan), and in 2012 from 68.7\% (Evelin) to $73.7 \%$ (Rumelia). It is influenced by varietal properties, climatic conditions and cultivation locality (Mareček et al., 2013).

In terms of technological quality, varieties Rumelia, Megan and Arwen can be evaluated as most suitable from presented varietal group. They are suitable mainly for direct kitchen use and production of various heat -treated products (Peksa, 2008).

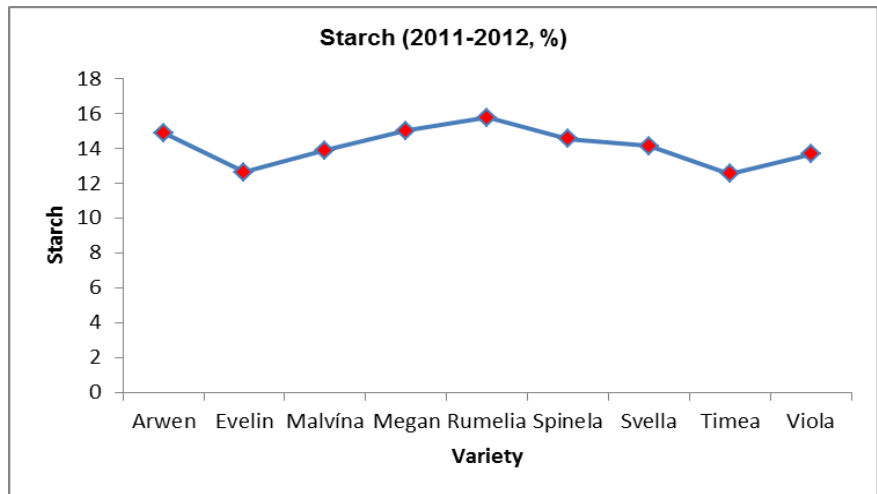

Figure 1 Starch (average years 2011-2012)

Sensory characteristics evaluation of varietal group was carried out by using a point descriptorfor dine value assessment. This evaluation was realized in six essential characteristics. Before cooking character A (appearance of fresh tubers) and after steaming characters B (tuber appearance), C (smell), D (taste), E (pulp firmness), F (darkening of tubers), while the heat treatment was performed with hot steam. Rating of tubers was exercised by seven trained evaluators with professional experience in potato quality assessment. 
Table 2 Sensory quality of evaluated varieties (points; production year 2011)

\begin{tabular}{cccccccc}
\hline Variety & A & B & C & D & E & F & Total \\
\hline Arwen & 7.2 & 10.8 & 8.0 & 23.6 & 11.8 & 7.8 & 69.2 \\
Evelin & 8.2 & 13.2 & 8.0 & 27.6 & 12.8 & 8.0 & 77.8 \\
Malvína & 8.0 & 12.2 & 7.8 & 23.8 & 11.0 & 7.2 & 70.0 \\
Megan & 8.2 & 13.2 & 8.0 & 25.4 & 12.2 & 8.0 & 75.0 \\
Rumelia & 8.0 & 12.0 & 7.8 & 24.8 & 12.0 & 6.6 & 71.2 \\
Spinela & 8.0 & 13.4 & 7.8 & 28.4 & 13.2 & 8.0 & 78.8 \\
Svella & 7.8 & 10.2 & 8.0 & 22.2 & 10.8 & 7.0 & 66.0 \\
Timea & 7.8 & 12.2 & 7.8 & 25.2 & 12.0 & 8.0 & 73.0 \\
Viola & 7.8 & 12.0 & 7.8 & 26.4 & 12.0 & 7.2 & 73.2 \\
\hline
\end{tabular}

Legend: A - appearance of fresh unpeeled tubers; B - tuber appearance on the surface and on cut after steaming; C - tuber smell; D - tuber taste and swallow ability; E - pulp firmness and it s cooking ability; $\mathrm{F}$ - darkening of tubers after heat treatment

Individual evaluation results according to the characters $\mathrm{A}$ to $\mathrm{F}$ are listed in Table 2 (harvest of 2011) and Table 3 (harvest of 2012). The most important feature from the group of sensory evaluated parameters is taste. In 2011, the highest rating reached varieties Spinella 78.8 points, 77.8 points Evelin and 75.0 points Megan (very good dine value). Other varieties achieved only good dine value.
In 2012 , a very good dine value achieved two varieties: Evelin 78.2 points and 76.8 points Spinella. Other ones were at the level of good dine value $(67.2-74.2$ points). Sensory characteristics are influenced by varietal features, cultivation technology, by quality of harvest and storage conditions. Generally, the value of sensory properties gradually decreases during storage (Lachman et al, 2012).

Table 3 Sensory quality of evaluated varieties (points; production year 2012)

\begin{tabular}{cccccccc}
\hline Variety & A & B & C & D & E & F & Total \\
\hline Arwen & 8.0 & 11.8 & 8.0 & 23.2 & 12.0 & 7.0 & 70.0 \\
Evelin & 8.0 & 13.2 & 8.0 & 28.2 & 13.0 & 7.8 & 78.2 \\
Malvína & 8.2 & 12.2 & 7.6 & 24.4 & 10.8 & 7.8 & 71.0 \\
Megan & 8.0 & 13.0 & 7.8 & 25.2 & 12.2 & 7.0 & 73.2 \\
Rumelia & 8.0 & 12.4 & 8.0 & 25.2 & 12.0 & 6.8 & 72.4 \\
Spinela & 7.8 & 13.0 & 8.0 & 26.8 & 13.2 & 8.0 & 76.8 \\
Svella & 7.8 & 10.8 & 8.0 & 22.2 & 11.2 & 7.2 & 67.2 \\
Timea & 8.0 & 12.2 & 8.2 & 23.2 & 10.2 & 7.8 & 69.2 \\
Viola & 8.0 & 12.0 & 7.8 & 26.2 & 12.2 & 8.0 & 74.2 \\
\hline
\end{tabular}

Legend: A - appearance of fresh unpeeled tubers; B - tuber appearance on the surface and on cut after steaming; $\mathrm{C}$ - tuber smell; $\mathrm{D}$ - tuber taste and swallow ability; $\mathrm{E}$ - pulp firmness and its cooking ability; $\mathrm{F}$ - darkening of tubers after heat treatment

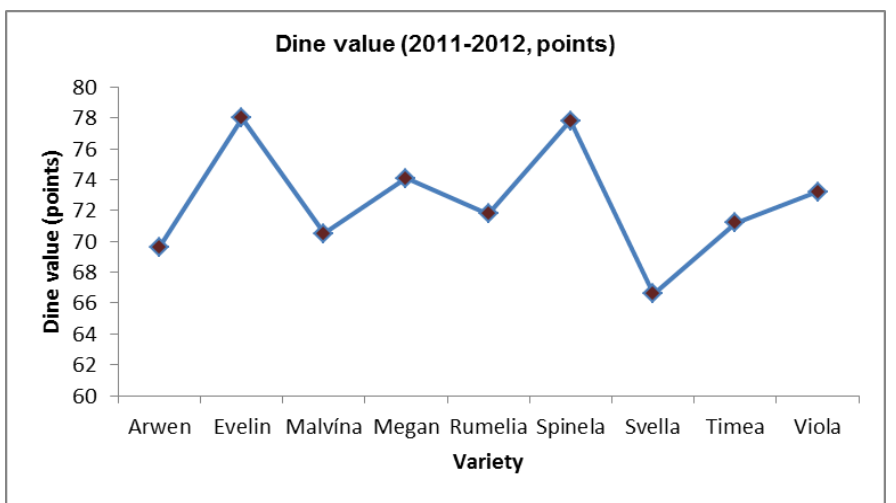

Figure 2 Dine value (average years 2011-2012)

\section{CONCLUSION}

Nine Slovak varieties of edible potatoes were evaluated in this work (Arwen, Evelin, Malvína, Megan, Rumelia, Spinela, Svella, Timea, Viola). Dry matter and starch content of tubers were assessed from the group of technological parameters. Within two evaluated years (2011 and 2012), the highest dry matter content of $21.8 \%$ was measured at variety Rumelia. The st arch content was at the same variety at the level of $15.8 \%$ (Figure 1). Sensory evaluation revealed very good dine value at varieties Evelin ( 78.0 points) and Spinela ( 77.8 point s). From evaluated group of varieties, Rumelia seems to have the highest technological quality (variety with red peel). The best sensory evaluation achieved variety Evelin, which is suitable for heat treatment by steaming and frying. Variety Spinela meets the technological and sensory requirements for subsequent food processing (Figure 2).

Acknowledgments: This work has been supported by project VEGA 1/0456/12.

\section{REFERENCES}

BÁRT A, J., ČEPL, J., DIVIŠ, J., HAMOUZ, K., JŮZL, M., VACEK, J. 2008. Potatoes. In PRUGAR, J. et al. 2008. Quality plants products at the beginning of the third millennium. Praha: VÚPaS, 241-257.

CZERKO, Z., ZGÓRSKA, K. 2008. Storage technology of potato for food processing. Advances of Agricultural Sciences Problem Issues. Warszawa : polish Academy of Sciences, 530, 69-79.
LACHMAN, J., HAMOUZ, K., ORSÁK, M., PIVEC, V., HEJTMÁNKOVÁ, K., PAZDERŮ, K., DVOŘÁK, P., ČEPL, J. 2012. Impact of selected factors Cultivar, storage, cooking and baking on the content af anthocyanins in colouredflesh potatoes. Food Chemistry, 133(4), 1107-1116. http://dx.doi.org/10.1016/j.foodchem.2011.07.077

MAREČEK, J., FIKSELOVÁ, M., KAČÁNIOVÁ, M., LÍŠKOVÁ, M. 2011. Content of saccharides and vitamin $\mathrm{C}$ in potato tubers stored under controlled atmosphere. Soil, plant and food interactions. Brno : MZLU, 268-272. MAREČEK, J., FRANČÁKOVÁ, H., BOJŇANSKÁ, T., FIKSELOVÁ, M., MENDELOVÁ, A., IVANIŠOVÁ, E. 2013. Carbohydrates in varieties of stored potatoes and influence of storage on quality of fried products. Journal of Microbiology, Biotechnology and Food Sciences, 2(Sp. is.), 1744-1753. MAREČEK, J., FRANČ́AKOVÁ, H., IVANIŠOVÁ, E., DRÁB, Š., POBEREŹNY, J., KEUT GEN, A. J., WSZELACZYŃSKA, E. 2014. Technological and sensory quality parameters of selected edible varieties of potatoes. Journal of Elementology, 19(2), 90.

STN 46 2211. Table value.

MARTENS, M., THYBO, A. K. 2000. Analysis of sensory assessors in texture profiling of potatoes by multivariate modelling. Food Quality and Preference, 11(4), 283-288. http://dx.doi.org/10.1016/s0950-3293(99)00045-2

PEKSA, A. Improving of processed potato quality in the production cycle. Advances of Agricultural Sciences Problem Issues. Warszawa : Polish Academy of Sciences, 530, 81-94.

POBEREŹNY, J., WSZELACZYŃSKA, E., 2011. Effect of bioelements (N, K, $\mathrm{Mg}$ ) and long-term st orage of potato tubers on quantitative and qualit ative losses. Part II. Content af dry mater and starch. Journal of Elementology, 16(2), $237-$ 246. http://dx.doi.org/10.5601/jelem.2011.16.2.07

SINGH, J., KAUR, L., RAO, M. A. 2009. Textural and Rheological Characteristics of Raw and Cooked Potatoes. In SINGH, J., KAUR, L. 2009. Advances in Potato Chemistry and Technology. New York : Academic Press, Elsevier, p. 249-271. ISBN 978-0-12-374349-7. http://dx.doi.org/10.1016/B978 0-12-374349-7.00009-X

WSZELACZYŃSKA, E., POBEREŹNY, J., ŽARY-SIKORSKA, E., MAREČEK, J. 2013. Wplyw miejsca uprawy i przechowywania bulw na wybrane cechy kulinarne trzech odmian ziemniaka. Inž. Ap. Chem., 52(2), 68-70. 